\title{
Prevalence of lower back pain and physical inactivity: the impact of psychosocial factors in pregnant women served by the Family Health Strategy
}

\author{
Prevalência de lombalgias e inatividade física: o impacto dos fatores psicossociais em \\ gestantes atendidas pela Estratégia de Saúde da Família
}

\author{
Wilma Ferreira Guedes Rodrigues ${ }^{1}$, Leila Rangel da Silva ${ }^{2}$, Maria Aparecida de Luca Nascimento ${ }^{3}$, Carlos Soares \\ Pernambuco ${ }^{4}$, Tania Santos Giani ${ }^{4}$, Estélio Henrique Martin Dantas ${ }^{4}$
}

\begin{abstract}
Objective: This study analyzed the impact of psychosocial factors on pregnant women with lower back pain and an associated lack of physical activity prior to pregnancy. Methods: The sample included 66 pregnant women who were randomly selected from a total of 84 patients in the waiting rooms of the Family Health Units in Cuitegí, Paraíba, from September to November 2009. An epidemiological questionnaire adapted from the Quebec Back Pain Disability Scale was used for data collection. The questions about back pain, physical activity, and psychosocial factors were emphasized. SPSS 16.0 was used for the data analysis. The prevalence of lower back pain and its relationship to gestational age, habitual physical activity, and psychosocial factors were studied using the descriptive statistics and relative percentages in the SPSS Crosstabs procedure. The odds ratio and 95\% confidence interval for lower back pain were calculated. Results: The prevalence of lower back pain was $75 \%$, which suggests that psychosocial factors were related to the presence of pain. Anxiety was reported in $42.8 \%$ of the women with lower back pain, and $38.7 \%$ of the women with lower back pain experienced physical fatigue at the end of the day. A higher percentage of pain (53\%) was noted in the women who did not exercise prior to pregnancy. Conclusion: Lower back pain prior to pregnancy is associated with lack of physical activity and with psychosocial factors in the Family Health Strategy patients of Cuitegí county.
\end{abstract}

Keywords: Pregnancy; Lower back pain; Motor activity

\section{RESUMO}

Objetivo: 0 objetivo deste estudo foi analisar o impacto nos fatores psicossociais de gestantes com queixas de lombalgias associada à falta de atividade física antes da gravidez. Métodos: A amostra foi composta por 66 gestantes, selecionadas aleatoriamente, de um total de 84, presentes nas salas de espera das Unidades de Saúde da Família no município de Cuitegí, Paraíba, no período de setembro a novembro de 2009. Para a coleta dos dados foi utilizado um questionário epidemiológico, adaptado da Quebec Back Pain Disability Scale, dandose ênfase às perguntas sobre dor lombar, atividade física e fatores psicossociais. Para análise dos dados aplicou-se o SPSS 16.0, para a estatística descritiva de percentual relativo e Crosstabs foi realizado para razão de prevalência entre presença da dor lombar e a relação com a idade gestacional, e a presença do hábito de praticar atividade física e fatores psicossociais. Para a dor lombar no grupo estudado, realizou-se o cálculo do odds ratio, com intervalo de confiança de $95 \%$. Resultados: A prevalência da dor lombar foi de $75 \%$, observando-se que os fatores psicossociais estão relacionados com a presença da dor. Das mulheres com dor lombar, 42,8\% referiram ansiedade e 38,7\% apresentaram cansaço físico no final do dia. Observou-se ainda um percentual maior de dor (53\%) nas mulheres que não praticavam atividades físicas antes da gravidez. Conclusões: A lombalgia associada à falta da atividade física antes da gravidez interfere em fatores psicossociais de gestantes atendidas pela Estratégia de Saúde da Família do município de Cuitegí.

Descritores: Gravidez; Dor lombar; Atividade motora

\section{INTRODUCTION}

Lower back pain affects the lowest part of the back and the gluteal fold, and it may radiate to the lower limbs. Lower back pain appears in three forms: pain in the spine, pain in the hip, and combined pain.

\footnotetext{
Study carried out at the Family Health Units - Cutegí (PB), Brazil.

' Centro Universitário de João Pessoa - UNIPÊ, João Pessoa (PB), Brazil.

${ }^{2}$ Alfredo Pinto School of Nursing, Universidade Federal do Estado do Rio de Janeiro - UNIRIO, Rio de Janeiro (RJ), Brazil.

${ }^{3}$ Center for Research and Experimentation and in Woman and Child Health Studies - NuPEEMC; Universidade Federal do Estado do Rio de Janeiro - UNIRIO, Rio de Janeiro (RJ), Brazil.

${ }^{4}$ Laboratory of Human Movement Biosciences - LABIMH, Universidade Federal do Estado do Rio de Janeiro - UNIRIO, Rio de Janeiro (RJ), Brazil.

Corresponding author: Wilma Ferreira Guedes Rodrigues - Rua Jose Maria Tavares de Melo, 67 - Jardim Luna - CEP 58034-220 - João Pessoa (PB), Brazil - Tel.: (83) 30215740 - E-mail: wilma_fgr@msn.com Received on: July 1, 2011 - Accepted on: Nov 1, 2011

Conflicts of interest: none
} 
It occurs in at least $50 \%$ of pregnant women worldwide $^{(1)}$. Various psychosocial factors are possible determinants of lower back pain in pregnancy: prepregnancy factors (e.g., age, educational background, the presence of lower back pain prior to pregnancy, the number of previous pregnancies, a sedentary lifestyle, and psychological and emotional factors); and pregnancy-related factors (e.g., biomechanical, hormonal, psychological, occupational factors, and weight gain $)^{(2)}$.

This type of pain is a common complaint during pregnancy, which has led health professionals who treat pregnant women to consider lower back pain as another pregnancy-related discomfort. However, lower back pain can cause symptoms that prevent pregnant women from leading a normal life, such as motor impairment, insomnia, and depression. Preventive measures and proper treatment are required ${ }^{(3)}$.

More than one-third of pregnant women mention lower back pain as a problem that causes serious stress by interfering with their daily activities and capacity for $\operatorname{work}^{(4)}$. The presence of psychological problems, such as depression, anxiety, stress, or other emotional disturbances, contributes to the manifestations of chronic pain and disability ${ }^{(5)}$. Stress, fear, anxiety, and pain duration affect the activation mechanism of the endorphin system, which modulates endogenous analgesia ${ }^{(6)}$. Patients who suffer from lower back pain and who have severe pain or fear of movement over a period of several months require treatment to fully recover ${ }^{(7)}$.

Physical activity is a predominant factor in efforts to reduce lower back pain, and various types of exercise are effective. This practice has led to a trend towards scientific studies on the benefits of movement for persons in special situations, especially pregnant women $^{(8,9)}$. Further studies are required to fill the current gaps in the knowledge of lower back pain and pregnancy.

Understanding the connections to physical activity and psychosocial factors in Northeast Brazil may contribute to prevention programs that assure a better quality of life for pregnant women.

\section{OBJECTIVE}

This study analyzed the impact of psychosocial factors in pregnant women at the Family Health Strategy (FHS) who complained of lower back pain prior to pregnancy that was associated with a lack of physical activity.

\section{METHODS}

This descriptive study used a sample of 66 pregnant women who were randomly selected from a total of
84 pregnant women in the unit. The sample had a proportion error of $20 \%$ and an estimation error of $4 \%$. Type I error was fixed at $5 \%$ with a confidence level of $95 \%$.

The women were recruited from the prenatal consultation waiting rooms at the FHS units in Cuitegí, (PB). The sample included $79 \%$ of the patients who met the inclusion criteria.

The Committee on Ethics in Research of the School of Santa Emília of RODAT in João Pessoa, (PB), approved this study (CEP: 244771). The data were collected from September to November 2009.

All of the participants met the following inclusion criteria: pregnant, registered with the FHS, residing in the community, and at least 18 years of age. The data were collected in a private and comfortable room.

The research team requested participation in the study. All of the women had equal opportunity to participate in the study. The women who agreed received information on the objectives of the study and signed an informed consent form. The Quebec Back Pain Disability Scale, which has questions assessing lower back pain, physical activity, and psychosocial factors, was used for the data collection ${ }^{(10)}$. The research nurse administered the questions with the support of the unit's health team. A researcher trained three community health agents, one from each micro-area, who assisted with the study.

The SPSS version 16.0 Crosstabs procedure was used to analyze the descriptive statistics and relative percentages. The prevalence of lower back pain was calculated by gestational age, physical activity, and psychosocial factors. The odds ratio (OR) and its $95 \%$ confidence interval (CI) were calculated to quantify the probability of developing lower back pain during pregnancy.

\section{RESULTS}

The majority of the women were between the twelfth and thirty-second weeks of pregnancy, with ages ranging between 23 and 35 years old. The majority $(79.0 \%)$ did not work outside the home. Most of the women (74.2\%) reported lower back pain during pregnancy. Many of the women $(65.2 \%)$ had completed primary school. The group characteristics as to weight, height, and Body Mass Index (BMI) are shown in table 1.

Table 1. The descriptive characteristics of the group $(n=66)$

\begin{tabular}{lccccccc}
\hline Characteristics & Average & $\begin{array}{c}\text { Standard } \\
\text { error }\end{array}$ & Mean & $\begin{array}{c}\text { Coefficient } \\
\text { of variance }\end{array}$ & $\begin{array}{c}\text { Standard } \\
\text { deviation }\end{array}$ & Minimum Maximum \\
\hline Weight & 5.21 & 0.425 & 5.30 & 3.6 & 1.90 & 49.0 & 54.0 \\
Height & 1.53 & 0.863 & 1.52 & 14.9 & 3.80 & 148.0 & 162.0 \\
BMl & 22.70 & 0.325 & 22.70 & 2.1 & 1.45 & 20.3 & 25.2 \\
\hline
\end{tabular}

BMI: Body mass index 
Table 2 illustrates the gestational ages of the pregnant women with lower back pain. Low back pain was 2.88 times more prevalent in the women with gestational ages between 16 and 28 weeks, and the odds of developing lower back pain were 5.5 times greater for these women $(95 \% \mathrm{CI}=0.76-9.28)$.

Table 2. The prevalence of lower back pain by gestational age $(n=66)$

\begin{tabular}{lccc}
\hline \multirow{2}{*}{ Gestational age } & \multicolumn{3}{c}{ Lower back pain } \\
\cline { 2 - 4 } & Yes n (\%) & No $\mathbf{~ ( \% ) ~}$ & Total n (\%) \\
\hline Less than 8 weeks & $5(7.5)$ & $4(6.0)$ & $9(13.6)$ \\
Between 8 and 16 weeks & $9(13.6)$ & $5(7.4)$ & $14(21.0)$ \\
Between 16 and 28 weeks & $26(39.4)$ & $6(9.0)$ & $32(48.4)$ \\
Greater than 28 weeks & $9(13.6)$ & $2(3.0)$ & $11(16.6)$ \\
Total & $49(74.2)$ & $17(25.4)$ & $66(100)$ \\
\hline
\end{tabular}

The pregnant women most frequently performed hydrogymnastics $(15 \%)$, followed by stretching and walking, but these modalities did not completely eliminate lower back pain. The odds of developing lower back pain were 3.77 times greater $(95 \% \mathrm{CI}=0.77-3.87)$ in the women who did not engage in physical activity prior to their pregnancies than in those who did, with a relative risk of $1.75(95 \% \mathrm{CI}=0.14-1.44)$. Fifty-three percent of the $74.2 \%$ of women who reported lower back pain did not engage in physical activity prior to pregnancy (Table 3 ).

Table 3. Lower back pain and physical activity prior to pregnancy $(n=66)$

\begin{tabular}{lccc}
\hline \multirow{2}{*}{ Pain } & \multicolumn{3}{c}{ Engaged in physical activity prior to pregnancy } \\
\cline { 2 - 4 } & Yes $\mathbf{n}(\%)$ & No $\mathbf{n}(\%)$ & Total $\mathbf{n}(\%)$ \\
\hline Yes & $14(21.2)$ & $35(53)$ & $49(74.2)$ \\
No & $8(12.1)$ & $9(13.6)$ & $17(25.7)$ \\
Total & $22(33.3)$ & $44(66.6)$ & $66(100)$ \\
\hline
\end{tabular}

The number of interpersonal relationships outside of the home (e.g., friends, work colleagues, and neighbors) and the moods of the women with lower back pain were assessed. The analysis of lower back pain and interpersonal relationships outside of the home revealed that $31.8 \%$ of the women with lower back pain had few friends, and $21.2 \%$ of the women reported no friends (Table 4).

Table 4. The prevalence of lower back pain by the number of interpersonal relationships $(n=66)$

\begin{tabular}{lccc}
\hline \multirow{2}{*}{ Interpersonal relationship } & \multicolumn{3}{c}{ Lower back pain } \\
\cline { 2 - 4 } & Yes $\mathbf{n}(\%)$ & No $\mathbf{n}(\%)$ & Total $\mathbf{n}(\%)$ \\
\hline None & $14(21.2)$ & $3(4.5)$ & $17(25.7)$ \\
Few & $21(31.8)$ & $7(10.6)$ & $28(42.4)$ \\
Enough & $7(10.6)$ & $4(6.0)$ & $11(16.6)$ \\
Many & $7(10.6)$ & $3(4.5)$ & $10(15.1)$ \\
Total & $49(74.2)$ & $17(25.6)$ & $66(100)$ \\
\hline
\end{tabular}

An analysis of mood and the presence of lower back pain revealed that $42.8 \%$ of the pregnant women felt mostly anxiety in the presence of pain, followed by irritation and sadness (Table 5).

Table 5. The prevalence of lower back pain by mood $(n=66)$

\begin{tabular}{lccc}
\hline \multirow{2}{*}{ Mood } & \multicolumn{3}{c}{ Lower back pain } \\
\cline { 2 - 4 } & Yes n (\%) & No $\mathbf{~ ( \% ) ~}$ & Total n (\%) \\
\hline Normal & $16(24.2)$ & $9(13.6)$ & $25(37.8)$ \\
Anxious & $21(31.8)$ & $2(3.0)$ & $23(34.8)$ \\
Sad & $3(4.5)$ & $1(1.5)$ & $4(6.0)$ \\
Irritated & $9(13.6)$ & $5(7.5)$ & $14(21.2)$ \\
Total & $49(74.2)$ & $17(25.6)$ & $66(100)$ \\
\hline
\end{tabular}

\section{DISCUSSION}

The present study examined the prevalence of lower back pain during pregnancy and its relationship to a lack of physical activity prior to pregnancy and psychosocial factors. Assessing the prevalence of painful symptoms in this investigation was important for demonstrating the difficulties that are encountered by women during pregnancy.

Because $65.2 \%$ of the participants had completed primary school, the women readily understood the QBPDS, including the interpretation of the questions and the instructions of the researchers.

The majority of the pregnant women in the study were approximately 25 years old (mean: 23.35 years) and between the 12th and 32nd weeks of pregnancy (mean: 23.31 weeks).

The prevalence of pain did not vary significantly by BMI in this study; the women were within normal BMI standards, with a mean of 22.7. No participant was considered obese or had a tendency to gain weight.

Lower back pain was present in more than $50 \%$ of the pregnant women; $75 \%$ of the pregnant women reported feeling lower back pain. These data corroborate previous studies of pregnant women in Brazil, Sweden, the United States, China, and Israel that found a spinal column and pelvic pain prevalence of between $50 \%$ to $80 \%$. The pregnant women in this study who had not engaged in physical activity prior to their pregnancies exhibited a high percentage of lower back pain (53\%), which suggests the importance of physical activity for preventing and/or improving the symptoms.

Therefore, these results are consistent with previous studies that have found less lumbar pain in pregnant women who maintain regular physical activity prior to and during pregnancy ${ }^{(17-20)}$. Physical activity prior to and during gestation provides many benefits to women. Lower back pain can be reduced and prevented by adopting a posture that corrects hyperlordosis that normally appears during gestation due to the expansion 
of the uterus in the abdominal cavity and the consequent shift in the center of gravity. Physical exercise contributes to adopting a new posture, which makes physical activity and daily work easier for pregnant women ${ }^{(21)}$.

Physical activity improves the principal factors that contribute to "lower back pain syndrome", including muscular weakness (primarily in the abdominal region) and poor flexibility in the joints of the back and lower $\operatorname{limbs}^{(22)}$. Therefore, consistent and properly chosen physical activity contributes to better posture and a lower incidence of lower back pain ${ }^{(23)}$.

The pregnant women who reported pain had difficulties in their interpersonal relationships outside of the home (e.g., fewer friends, work colleagues, and neighbors). Poor social relationships and limited cooperation with colleagues and friends are strongly associated with a high rate of lower back pain ${ }^{(24)}$. Similarly, a commitment to social, professional, and affective relationships reduces pain intensity ${ }^{(25)}$.

Individuals with additional domestic responsibilities or poor satisfaction with their social contacts exhibit a 1.5 times greater probability of pain than people who do not report these circumstances ${ }^{(26)}$. The majority of the pregnant women who suffered from pain exhibited mood changes. Mood alterations in depressed patients increase pain sensation $^{(27)}$. Increased anxiety can trigger problems during pregnancy, birth, puerperium, and conception $^{(28)}$.

Therefore, anxiety must be controlled if the effects of pain are to be minimized. All human experiences, including those that cause pain, involve physical and emotional components. Depression and anxiety are most commonly associated with chronic pain. Mood can interfere with the interpretation and reporting of pain ${ }^{(25)}$. The painful lumbar symptoms persist in this segment of the population during pregnancy; depending on the degree of pain, symptoms can last for several years after birth if not treated ${ }^{(29)}$.

\section{CONCLUSIONS}

The elevated prevalence of lower back pain in the pregnant women utilizing the FHS was related to a lack of physical activity. This result suggests that women who engage in physical activity prior to pregnancy are less affected by lower back pain. Moreover, lower back pain was also related to psychosocial alterations, including those in interpersonal and professional relationships, pleasure, and leisure, which negatively affect the quality of life in pregnant women. Further studies on lower back pain during pregnancy and its effects on health should be performed to promote preventive measures and improve women's quality of life during this important period.

\section{REFERENCES}

1. Johansson G, Norén L, Ostgaard HC, Ostgaard S. Lumbar back and posterior pelvic pain during pregnancy: a 3 -year follow-up. Eur Spine J. 2002;11(3):267-71.

2. De Conti MHS, Calderon IMP, Consonni EB, Prevedel TTS, Dalbem I, Rudge MVC. Efeitos de técnicas fisioterápicas sobre os desconfortos músculoesqueléticos da gestação. Rev Bras Ginecol Obstet. 2003;25(9):647-54.

3. Novaes FS, Shimo AKK, Lopes MHBM. Lombalgia na gestação. Rev Latinoam Enferm. 2006;14(4):620-4.

4. Ferreira CHJ, Nakano AMS. Reflexões sobre as bases conceituais que fundamentam a construção do conhecimento acerca da lombalgia na gestação. Rev Latinoam Enferm. 2001;9(3):95-100.

5. Weiner DK, Rudy TE, Kim YS, Golla S. Do medical factors predict disability in older adults with persistent low back pain? Pain. 2004;112(1-2):214-20.

6. Teixeira MJ, Fisiopatologia da dor neuropática. Rev Med.1999;78(2):53-84.

7. Ostelo RW, de Vet HC, Vlaeyen JW, Kerckhoffs MR, Berfelo WM, Wolters $\mathrm{PM}$ et al. Behavioral graded activity following first-time lumbar disc surgery: 1-year results of a randomized clinical trial. Spine (Phila Pa 1976). 2003;28(16): 1757-65.

8. Martins PF, Silva JLP. Tratamento da lombalgia e dor pélvica posterior na gestação por um método de exercícios. Rev Bras Obstet Ginecol. 2005;27(5):275-282.

9. Nifa GS, Moreira OC, Oliveira CE, Teodoro BG. A importância do exercício físico para gestantes. @rgumentandum. 2010. [citado 2011 Abr]. Disponivel em: http://www.sudamerica.edu.br/revista/?p=67

10. Bréder VF, Dantas EHM, Silva MAG, Barbosa LG. Lombalgia e fatores psicossociais em motoristas de ônibus urbano. Fitness \& Performance Journal. 2006;5(5):295-299.

11. Olsson C, Nilson-Wikmar L. Health-related quality of life and physical ability among pregnant women with and without back pain in late pregnancy. Acta Obstet Gynecol Scand. 2004;83(4):351-7.

12. Ostgaard HC, Anderson GB, Shultz AB, Miller JA. Influence of some biomechanical factors on low-back pain in pregnancy. Spine. 1993;18(1):61-5.

13. Ostgaard HC, Anderson GBJ, Karlsson K. Prevalence of back pain in pregnancy. Spine. 1991;16(5):549-52

14. Ostgaard HC, Zetherstrom G, Roos-Hansson E. The posterior pelvic pain provocation test in pregnant women. Eur Spine. 1994;3(5):258-60.

15. To WW, Wong MW. Factors associated with back pain symptoms in pregnancy and the persistence of pain 2 years after pregnancy. Acta Obstet Gynecol Scand. 2003;82(12):1086-91.

16. Franklin ME, Conner-Kerr T. An analysis of posture and back pain in the first and third trimesters of pregnancy. J Orthop Sports Phys Ther. 1998;28(3):133-8.

17. Balderston KD, Carlson HL, Carlson NL, Pasternak BA. Understanding and managing the back pain of pregnancy. Curr Womens Health Rep. 2003:3(1):65-71.

18. Barnes R, Gonzalvez S, Kulig K, Landel R, Requejo SM. The use of a modified classification system in the treatment of low back pain during pregnancy: a case report. J Orthop Sports Phys Ther; 2002;32(7):318-26.

19. Mogren IM, Previous physical activity decreases the risk of low back pain and pelvic pain during pregnancy. Scand J Public Health; 2005;33(4): 300-6.

20. Commissaris DA, Nilsson-Wikmar LB, Van Dieën JH, Hirschfeld H. Joint coordination during whole-body lifting in women with low back pain after pregnancy. Arch Phys Med Rehabil; 2002;83(9):1279-89.

21. Hartmann S, Bung P. Physical exercise during pregnancy: physiological considerations and recommendations. J Perinat Med; 1999;27(3):204-15.

22. Jesus GT, Marinho IS. Causas de lombalgia em grupos de pessoas sedentárias e praticantes de atividades físicas [Internet]. [citado 2011 Nov 1]. Disponível em: URL: http://www.efdeportes.com.

23. Mann L, Kleinpaul JF, Teixeira CS, Konopka CK. Dor lombo-pélvica e exercício Físico durante a gestação. Fisiot Mov. 2008;21(2):99-105 
24. Valat JP. Factors involved in progression to chronicity of mechanical low back pain. J Bone Spine. 2005;75(3):193-195.

25. Pimenta CA. Fundamentos teóricos da dor e de sua avaliação. In: Carvalho MM, organizador. Dor: um estudo multidisciplinar. São Paulo: Summus; 1999.

26. Thorbjörnsson CO, Alfredsson L, Fredriksson K, Köster M, Michélsen H, Vingård E, et al. Psychosocial and Physical risk factors associated with low back pain: a 24-year follow up among women and men in a broad range of occupations. Occup Environ Med. 1998;55(2):84-90.
27. Anthony R, Scialli MD. Evaluating chronic pelvic pain. A consensus recommendation. J Reproductiv Med. 1999;44(11):945.

28. Araújo DM, Pacheco AH, Pimenta AM, Kac G. Prevalência e fatores associados a sintomas de ansiedade em uma coorte de gestantes atendidas em um centro de saúde do município do Rio de Janeiro. Rev Bras Saúde Mater Infant. 2008;8(3):333-40.

29. Batista DC, Chiara VL, Gugelmin SA, Martins PD. Atividade física e gestação: saúde da gestante não atleta e crescimento fetal. Rev Bras Saude Mater Infant. 2003;3(2):151-8. 